\title{
Influence of structural parameters of the masonry on effective elastic properties and strength
}

\author{
A.I. Grishchenko; \\ A.S. Semenov; \\ S.G. Semenov; \\ B.E. Melnikov, \\ St.Petersburg Polytechnic University
}

\begin{abstract}
Two phase masonry model, which contains elastic mortar and elastic bricks, is analyzed numerically in order to evaluate sensitivity of effective elastic moduli and strength properties to a deviation in the masonry structural parameters. Different methods of masonry homogenization are studied.

Effective elastic moduli of the masonry representative volume element are obtained by means of direct finite element simulation and homogenization procedure. Influence of variation in the heterogeneous material microstructure characteristics (influence of brick aspect ratio and orientation angle) on the local stress-strain state and mechanical properties of the representative volume element of the composite considered is analyzed. Mechanical properties obtained by direct finite element modeling and other methods in various literary sources are compared.

These studies are relevant for the design of composite materials with a structure similar to masonry.

Key words: masonry; composite materials; representative volume element; homogenization; numerical experiment; boundary conditions of periodicity; effective elastic moduli; finite element method; PANTOCRATOR
\end{abstract}

\section{Introduction}

Masonry is a two phase composite material consisting of brick and mortar joints, generally arranged periodically. It is important to study the influence of masonry structural parameters on its deformation characteristics for the reasons of design and retrofitting masonry structures. Computer simulation of masonry deformation and failure processes can be used as a viable alternative to otherwise expensive and time-consuming laboratory and field experiments.

The most common approach is to model each brick and each mortar joint in the assembly, where linear and nonlinear constitutive behaviors of bricks and mortar can be considered. However, these methods require intensive computational efforts [1-4].

On the other hand, masonry can be treated as an effectively elastic continuum. A way of modeling a structure made of heterogeneous materials without treating all of the heterogeneities individually consists in trying to replace the heterogeneous medium by an equivalent homogeneous medium (EHM) endowed with the so-called effective properties.

Pande et al. [5] proposed a multilayer model to estimate effective elastic properties of masonry. Effective properties of a multilayered system with alternating joints are obtained in a closed form on the basis of equality of strain energy. A multilayer solution is first applied to homogenize the horizontal strip, and then used again to integrate the above homogenized strips with horizontal bed joints (Fig. 1b). Pietruszczak and Niu [6] also proposed a two-step homogenization scheme. At the first stage, they considered a homogeneous matrix formed from bricks with aligned head joints as inclusions. Equivalent elastic properties of the medium can be found using Eshelby's solution for an elliptic cylinder inclusion in combination with the Mori-Tanaka mean field theory [7]. Effective properties are defined through mechanics of the laminate material, homogenized medium that has been formed at the first step and continuous bed joints. The scheme is also illustrated in Fig. 1c. Bati et al. [8] suggested using aligned elliptical cylinders to approximate rectangular bricks (Fig. 1d).

None of the above methods have explicitly taken into account the specific pattern of brick and mortar, nor have fully exploited the periodicity of geometry, stress, strains, as well as other field quantities. In this paper, authors propose implementing a periodic homogenization method in order to model masonry structures. Gang Wang et al. also proposed implementing a periodic homogenization method to model masonry structures [9]. A periodic model is shown in Figure 1e.

Grishchenko A.I. Semenov A.S., Semenov S.G., Melnikov B.E. Influence of structural parameters of masonry on effective elastic properties and strength 


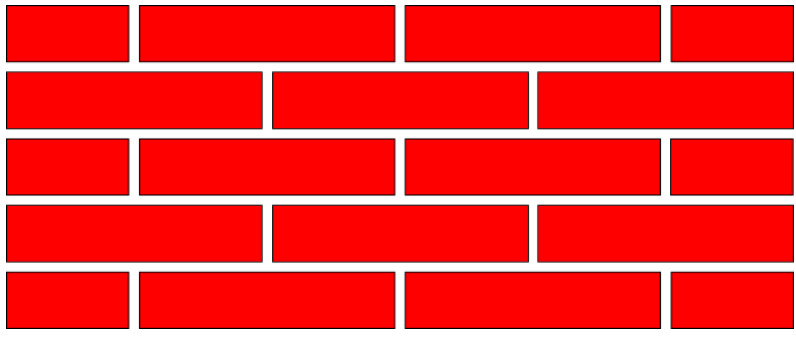

a) Masonry

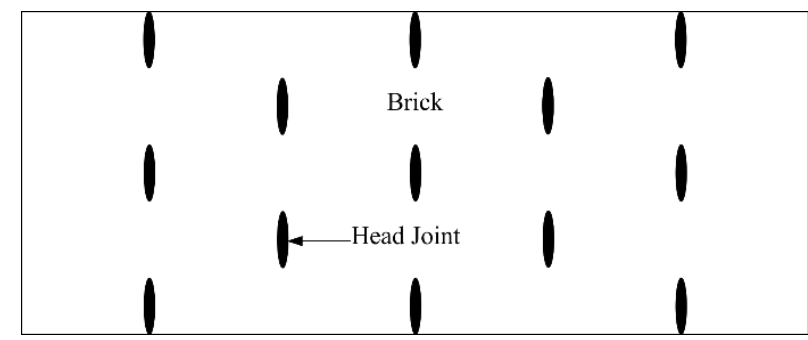

c) Two-step model [6]

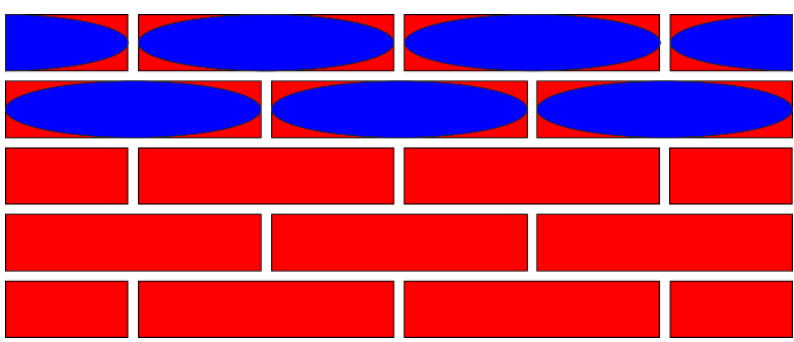

d) Elliptical cylinder model [8]

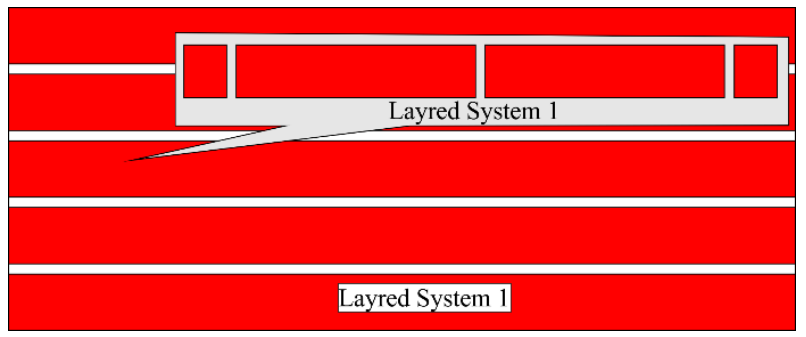

b) Multilayer model [5]
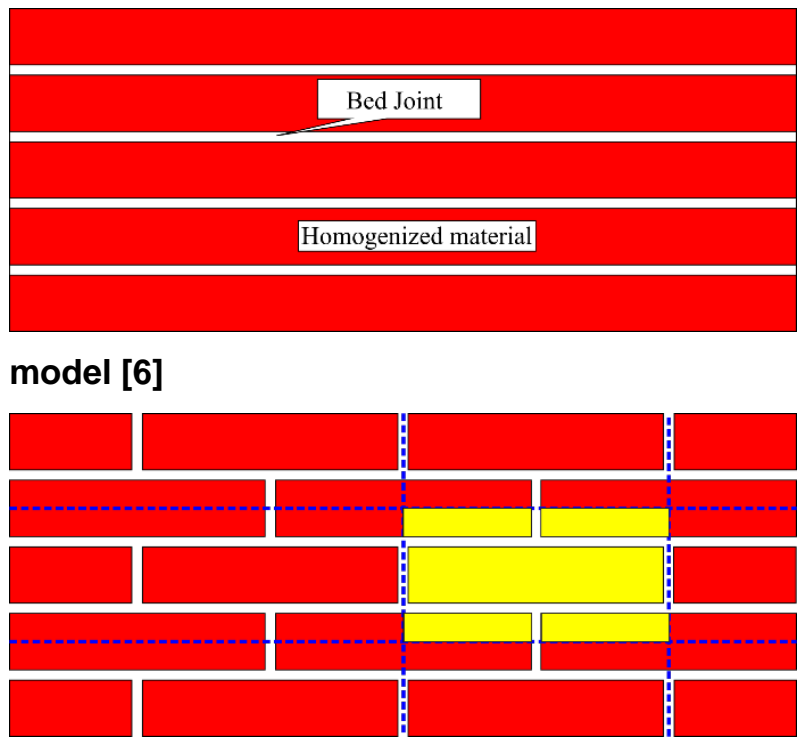

e) Periodic model [9]

Figure 1. Homogenization models for masonry structure

\section{The representative Volume Element}

Effective properties are calculated on the base of spatial averaging of the stress-strain state within the representative volume element (RVE) of a material. The RVE can be introduced for a material with statistically uniform distribution (ergodic hypothesis) taking into account the scale-separability of heterogeneities. In this case the least volume containing all the a priori statistical information on the distribution and morphology of the material heterogeneities can be introduced correctly.

The simplest two-dimensional variant of RVE (unit cell) (Fig. 2) is presented by the central rectangular inclusion and four fragments of neighboring undeflected inclusions ( $1 / 4$ area of each).

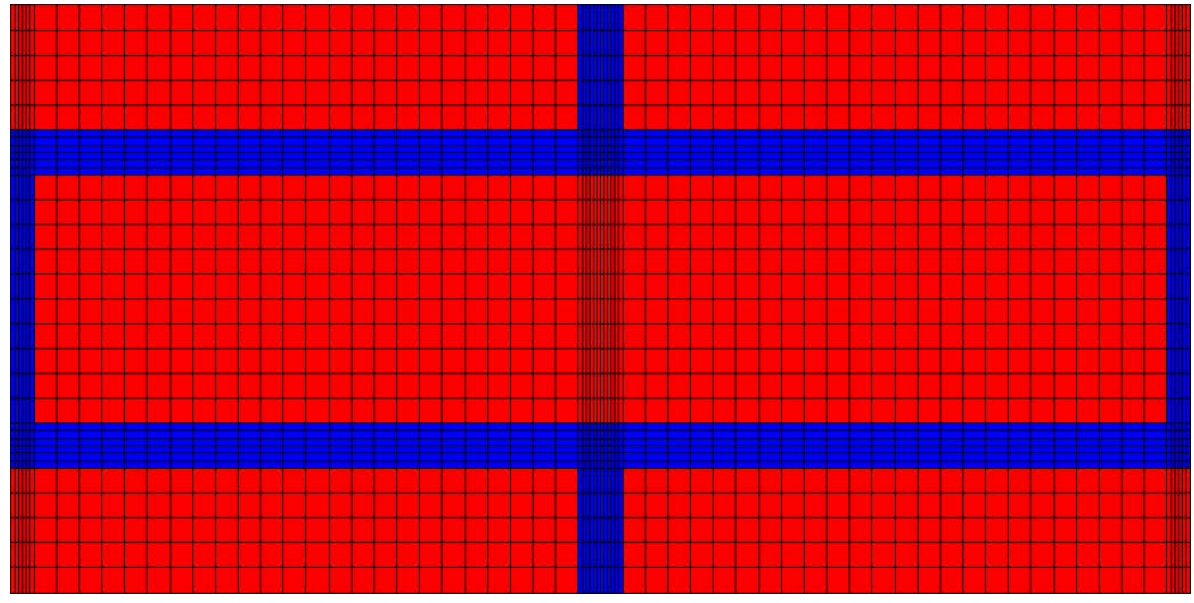

Figure 2. FE model of masonry RVE

Grishchenko A.I. Semenov A.S., Semenov S.G., Melnikov B.E. Influence of structural parameters of masonry on effective elastic properties and strength 


\section{Results of FE Modeling of Deformation Processes of Material RVE} subtasks:

Finite element simulations of deformation processes of RVE are aimed at solving two main

- identification of effective mechanical properties of the material RVE (homogenization problem);

- obtaining extreme values of stress fields within heterogeneous RVE for subsequent strength analysis (heterogenization problem).

\subsection{Effective Elastic Properties}

Effective elastic properties of masonry composite RVE are found by FE homogenization methods. It is supposed that effective properties of homogenized masonry correspond to an orthotropic elastic material, for which Hooke's law can be written as:

$$
\overline{\boldsymbol{\varepsilon}}={ }^{4} \overline{\mathbf{C}} \cdot \cdot \overline{\boldsymbol{\sigma}}
$$

where

$$
\overline{\boldsymbol{\varepsilon}}=\frac{1}{V_{R V E}} \int_{V_{R V E}} \boldsymbol{\varepsilon} d V
$$

is the spatial averaged strain tensor,

$$
\overline{\boldsymbol{\sigma}}=\frac{1}{V_{R V E}} \int_{V_{R V E}} \boldsymbol{\sigma} d V
$$

is the spatial averaged stress tensor, ${ }^{4} \overline{\mathbf{C}}$ is the tensor of effective elastic compliances of the $4^{\text {th }}$ rank. The bar over tensors indicates correspondence to the homogenized material.

For orthotropic materials the tensor ${ }^{4} \overline{\mathbf{C}}$ in its own axes of anisotropy corresponds to the symmetric matrix of elastic compliances $[\overline{\mathbf{C}}]$ with the following structure:

$$
[\overline{\mathbf{C}}]=\left[\begin{array}{cccccc}
\frac{1}{\bar{E}_{1}} & -\frac{\bar{v}_{21}}{\bar{E}_{2}} & -\frac{\bar{v}_{31}}{\bar{E}_{3}} & 0 & 0 & 0 \\
-\frac{\bar{v}_{12}}{\bar{E}_{1}} & \frac{1}{\bar{E}_{2}} & -\frac{\bar{v}_{32}}{\bar{E}_{3}} & 0 & 0 & 0 \\
-\frac{\bar{v}_{13}}{\bar{E}_{1}} & -\frac{\bar{v}_{23}}{\bar{E}_{2}} & \frac{1}{\bar{E}_{3}} & 0 & 0 & 0 \\
0 & 0 & 0 & \frac{1}{\bar{G}_{12}} & 0 & 0 \\
0 & 0 & 0 & 0 & \frac{1}{\bar{G}_{23}} & 0 \\
0 & 0 & 0 & 0 & 0 & \frac{1}{\bar{G}_{31}}
\end{array}\right], \quad \frac{\bar{v}_{12}}{\bar{E}_{1}}=\frac{\bar{v}_{21}}{\bar{E}_{2}}, \frac{\bar{v}_{13}}{\bar{E}_{1}}=\frac{\bar{v}_{31}}{\bar{E}_{3}}, \frac{\bar{v}_{23}}{\bar{E}_{2}}=\frac{\bar{v}_{32}}{\bar{E}_{3}} .
$$

Elastic moduli are determined on the basis of relations $\bar{E}_{i}=\frac{\bar{\sigma}_{i i}}{\bar{\varepsilon}_{i i}}, \bar{v}_{i j}=-\frac{\bar{\varepsilon}_{j j}}{\bar{\varepsilon}_{i i}}$.

2D boundary value problems are solved assuming the plane stress condition. In order to determine the two elastic moduli $\bar{E}_{1}$ and $\bar{E}_{2}$ it is necessary to solve only two boundary value problems with boundary conditions for tension (or compression) in the directions of the anisotropy axes (in the vertical and in the horizontal directions for the RVE in Figure 2).

Mechanical properties of the individual components correspond to the isotropic material. The elastic moduli of masonry components are taken from the literature $[9,10]$.

Grishchenko A.I. Semenov A.S., Semenov S.G., Melnikov B.E. Influence of structural parameters of masonry on effective elastic properties and strength 
Table 1. Normal elastic moduli of the individual components of mansory.

\begin{tabular}{|c|c|c|}
\hline & E, GPa & $\boldsymbol{v}$ \\
\hline Brick & 11 & 0.2 \\
\hline Mortar & 2.2 & 0.25 \\
\hline
\end{tabular}

Normal brick dimensions are $I=250 \mathrm{~mm}$ (length), $h=55 \mathrm{~mm}$ (height) (bricks aspect ratio $l / h=4.54$ ). Normal mortar joints are $10 \mathrm{~mm}$ thick (these dimensions correspond to the sizes of brick $0.8 \mathrm{NF}[\mathbf{1 1}])$.

Evaluation of the accuracy of numerical solutions is based on the analysis of practical convergence of the effective elastic moduli with an increasing number of unit cells and number of finite elements. The upper and lower boundaries for moduli are obtained using boundary conditions for displacements and for tractions. Three types of boundary conditions are applied and compared:

- kinematic uniform boundary condition

$$
\left.\mathbf{u}\right|_{S_{u}}=\overline{\boldsymbol{\varepsilon}}^{*} \cdot \mathbf{r},
$$

- static uniform boundary condition

$$
\left.\mathbf{n} \cdot \boldsymbol{\sigma}\right|_{S_{\sigma}}=\mathbf{n} \cdot \overline{\boldsymbol{\sigma}}^{*},
$$

- periodicity condition

$$
\left.\mathbf{u}\right|_{S_{u_{1}}}=\left.\mathbf{u}\right|_{S_{u_{2}}}+\overline{\boldsymbol{\varepsilon}}^{*} \cdot\left(\mathbf{r}_{1}-\mathbf{r}_{2}\right),
$$

where $\overline{\boldsymbol{\varepsilon}}^{*}$ and $\overline{\boldsymbol{\sigma}}^{*}$ are prescribed constant symmetric tensors corresponding to different possible states (axial tensions or shears), $\mathbf{r}$ is the radius-vector. The periodicity condition (7) can be rewritten in the form $\left.\mathbf{u}\right|_{S_{u}}=\overline{\boldsymbol{\varepsilon}}^{*} \cdot \mathbf{r}+\tilde{\mathbf{w}}$, where fluctuation $\tilde{\mathbf{w}}$ is periodic, i.e., $\tilde{\mathbf{w}}$ takes the same values on opposite sides of RVE. In this case the traction $\mathbf{n} \cdot \boldsymbol{\sigma}$ also takes opposite values on opposite sides. The boundary conditions (5)-(7) satisfy the Hill homogeneity condition and provide existence and uniqueness of the solution to the corresponding boundary value problems.

As a result of multivariant computational experiments, it has been found that by using periodicity conditions (7) satisfactory accuracy (close enough to the asymptotic value) is achieved (Fig. 3) even by using RVE including $1 / 4$ of the unit cell in Figure 1 whereas with the boundary conditions (5) and (6) convergence is achieved (Fig. 2) only if RVE includes $4 \times 4$ unit cells or more. The use of (7) allows reducing significantly the dimension of FE model and the computation time. The finite element models are shown in Figure 4.

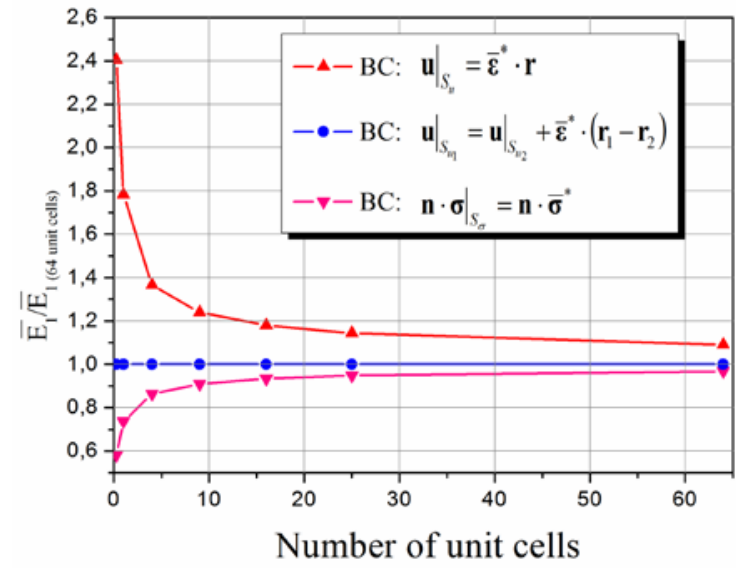

a)

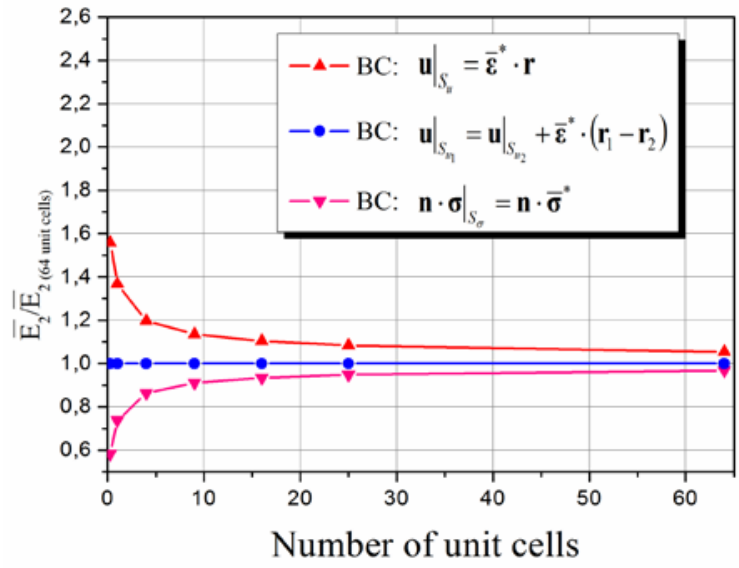

b)

Figure 3. Dependence of the effective elastic moduli:

a) $\bar{E}_{1}$ (in the horizontal direction) and b) $\bar{E}_{2}$ (in the vertical direction) on the number of unit cells.

Grishchenko A.I. Semenov A.S., Semenov S.G., Melnikov B.E. Influence of structural parameters of masonry on effective elastic properties and strength 


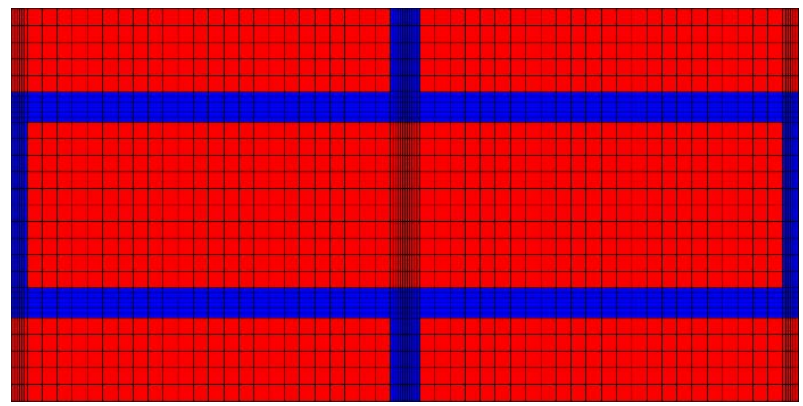

a)

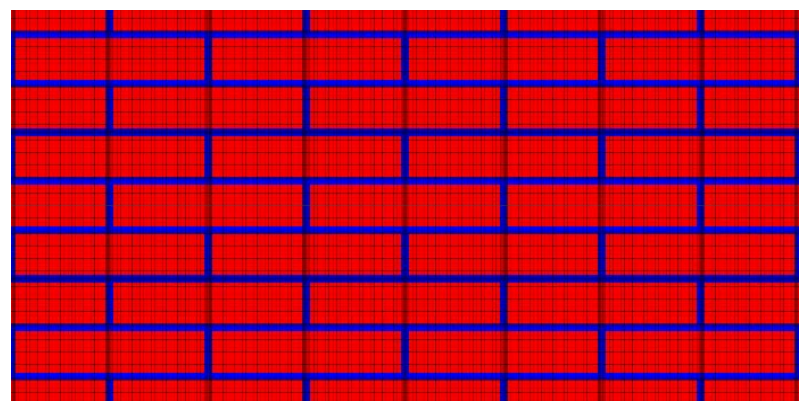

c)

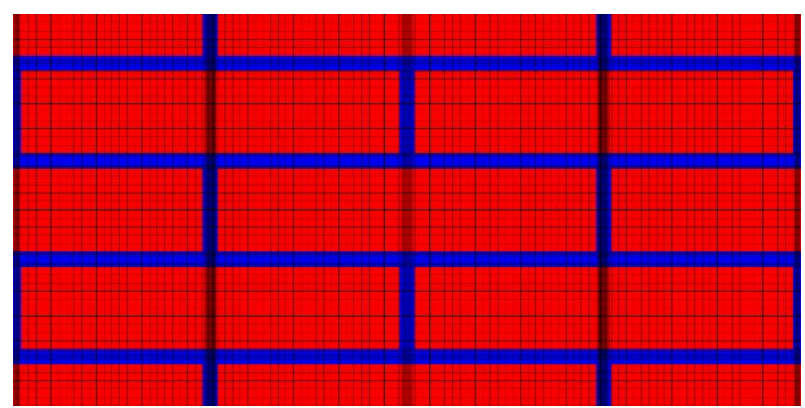

b)

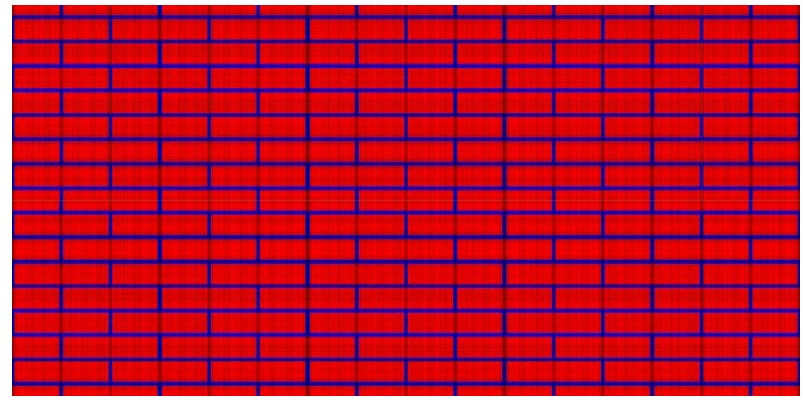

d)

Figure 4. Finite element model with a different number of unit cells: a) $1 \times 1$ unit cells,

b) $2 \times 2$ unit cells, c) $4 \times 4$ unit cells, d) $8 \times 8$ unit cells

The computations have been performed using the finite element software package PANTOCRATOR [12], which makes it possible to automatically generate discrete models of RVE arbitrary geometry, obtain solutions of boundary problems, determine the effective elastic moduli and strength properties of RVE, and to analyze distribution of stress and strain fields.

\subsection{Influence of Young's Modulus of Mortar}

In modern constructions different types of bricks and mortar are used [13]. Due to this fact, it is necessary to study the effect of elastic properties of the brick on the stress-strain state and on the effective elastic moduli of the masonry.

In order to evaluate the influence of the Young's modulus of mortar on the effective elastic moduli of RVE the FE computations are carried out with different Young's modulus of mortar: 1, 2, 4, 6, 8, $10 \mathrm{GPa}$. The results of computational experiments have shown that the Young's modulus of mortar exerts considerable influence on the effective elastic moduli (Fig. 5). The increase of the Young's modulus of mortar from $2 \mathrm{GPa}$ up to $10 \mathrm{GPa}$ leads to increases of $\bar{E}_{1}$ by $21.6 \%$ and of $\bar{E}_{2}$ by $68,6 \%$.

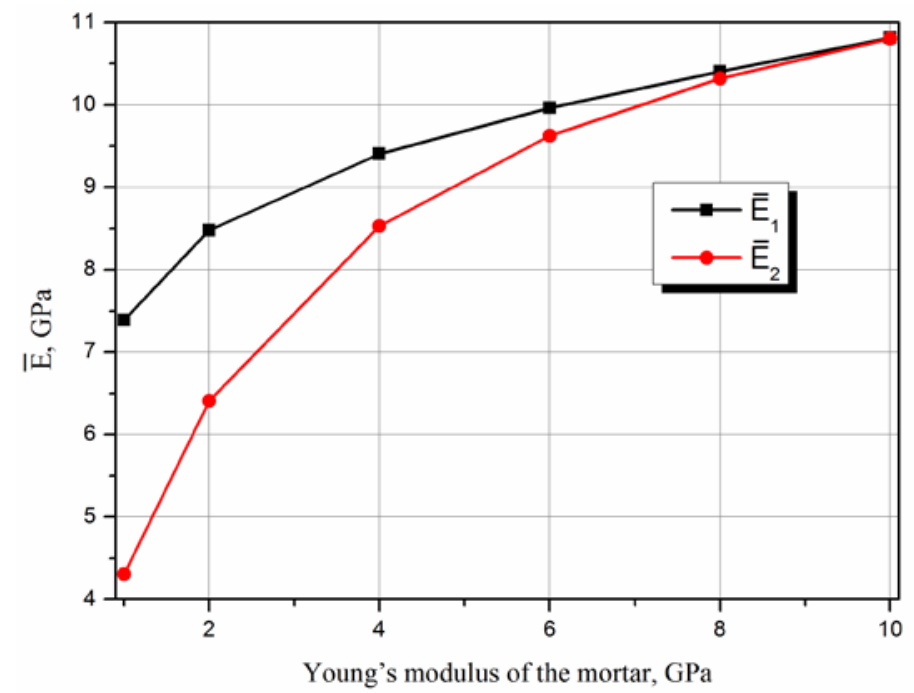

Figure 5. Dependence of the elastic moduli of masonry RVE on the Young's modulus

Grishchenko A.I. Semenov A.S., Semenov S.G., Melnikov B.E. Influence of structural parameters of masonry on effective elastic properties and strength 


\subsection{Influence of Brick Orientation}

So as to evaluate the effect of the angular orientation of the brick on the stress-strain state and on the effective elastic moduli of RVE the FE computations are carried out for three different deviation angles of the bricks from horizontal direction: $0^{\circ}, 2^{\circ}$ and $4^{\circ}$ (Fig. 6). The results of computational experiments have shown that rotation of a single brick does not practically affect the effective elastic moduli $\bar{E}_{1}, \bar{E}_{2}$ (difference is less than $1 \%$ ), but it has considerable influence on the level of maximum stress intensity (Fig. 7).

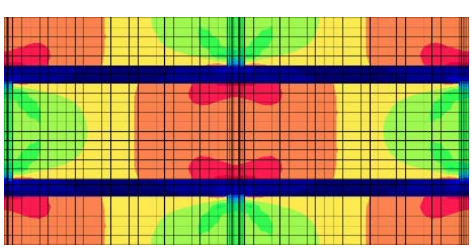

a)

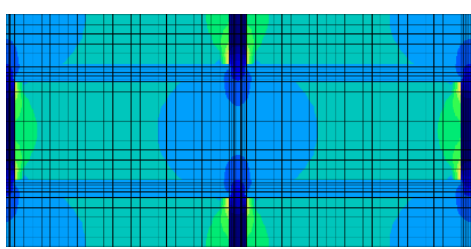

d)

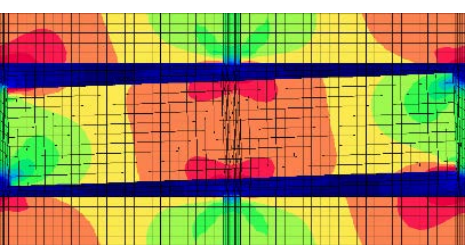

b)

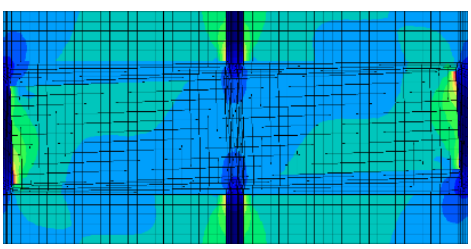

e)

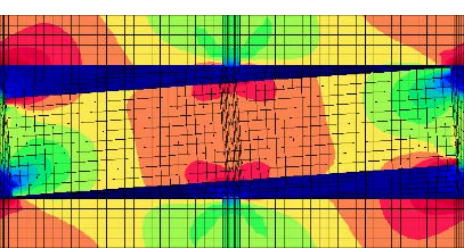

c)

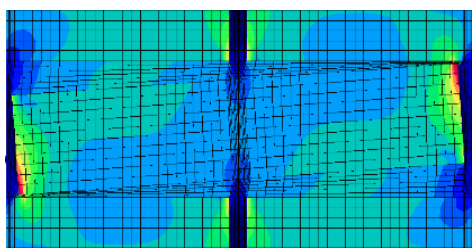

f)

Figure 6. Von Mises stress intensity fields in the masonry RVE under horizontal compression with rotation of single brick at: a) $0^{\circ}$, b) $2^{\circ}$, b) $4^{\circ}$; under vertical compression with rotation of single brick at: d) $0^{\circ}$, e) $2^{\circ}$, f) $4^{\circ}$

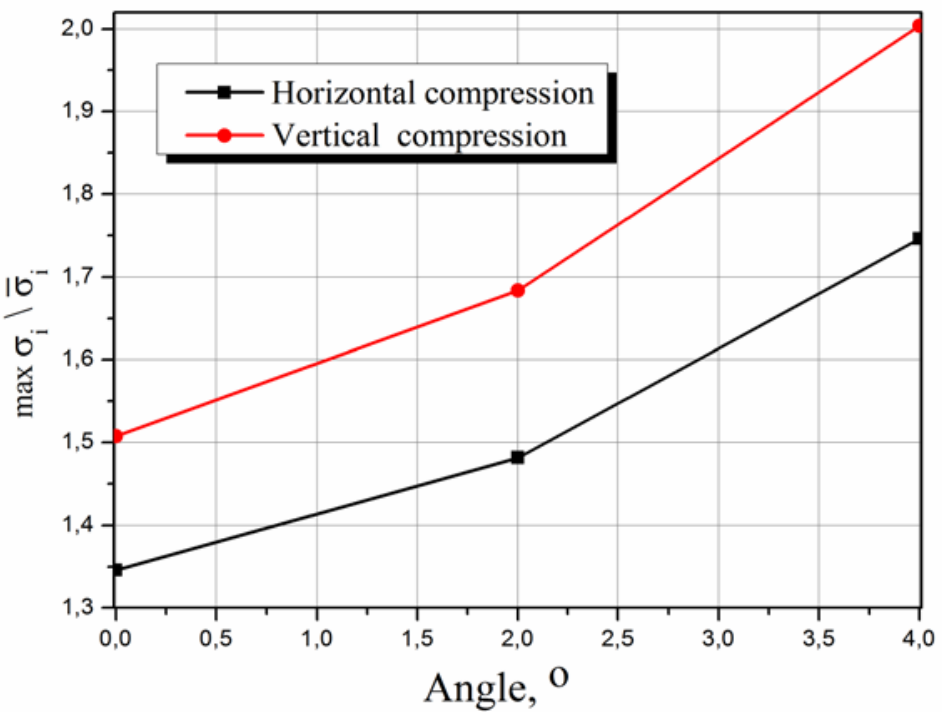

Figure 7. Dependence of the maximum von Mises stress intensity on the central brick rotation angle

The obtained results allow us to assume that the disorder of brick leads to increase of stresses in the masonry RVE. An ideal structure without brick disorientation has a maximum strength. Extremal stresses are observed at brick corners.

\subsection{Influence of Mortar Thickness}

In order to evaluate an influence of the mortar thickness on the stress-strain state and the effective elastic moduli of RVE, FE calculations are carried out with different thickness of mortar: $5,10,20, \ldots$, $70 \mathrm{~mm}$. The results of the computational experiments have shown that the thickness of mortar exerts considerable influence on the effective elastic moduli (Fig. 8) and on the von Mises stress intensity averaged over the whole volume of RVE and over its individual components (Fig. 9). Increase of the mortar thickness from $10 \mathrm{~mm}$ up to $30 \mathrm{~mm}$ leads to decrease of $\bar{E}_{1}$ by $40.2 \%$ and $\bar{E}_{2}$ by $54 \%$.

Grishchenko A.I. Semenov A.S., Semenov S.G., Melnikov B.E. Influence of structural parameters of masonry on effective elastic properties and strength 
The same increase of the mortar thickness under compression in horizontal direction leads to the diminishing von Mises stress intensity:

- by $39.8 \%$ for averaging over the whole volume of RVE;

- by $39.8 \%$ for averaging over the whole volume of brick;

- by $12.9 \%$ for averaging over the whole volume of mortar.

The same increase of the mortar thickness under compression in vertical direction leads to the decreasing von Mises stress intensity:

- $\quad$ by $53.8 \%$ for averaging over the whole volume of RVE;

- by $48.8 \%$ for averaging over the whole volume of brick;

- by $46.6 \%$ for averaging over the whole volume of mortar.

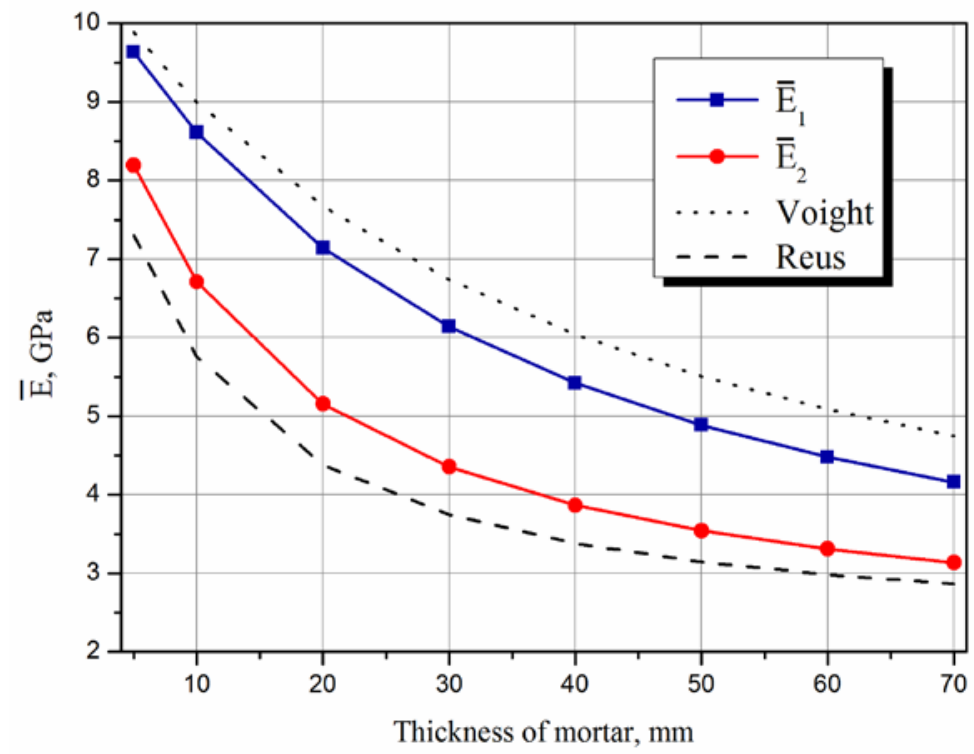

Figure 8. Influence of the thickness of mortar on the effective elastic moduli. Upper and lower curves correspond to the analytical estimations by Voigt (averaging of component stiffnesses) and by Reuss (averaging of component compliances)

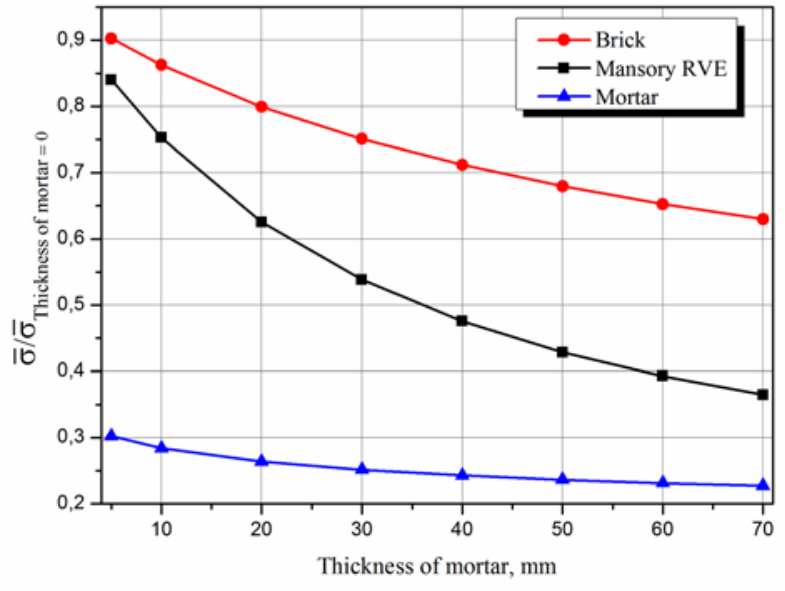

a)

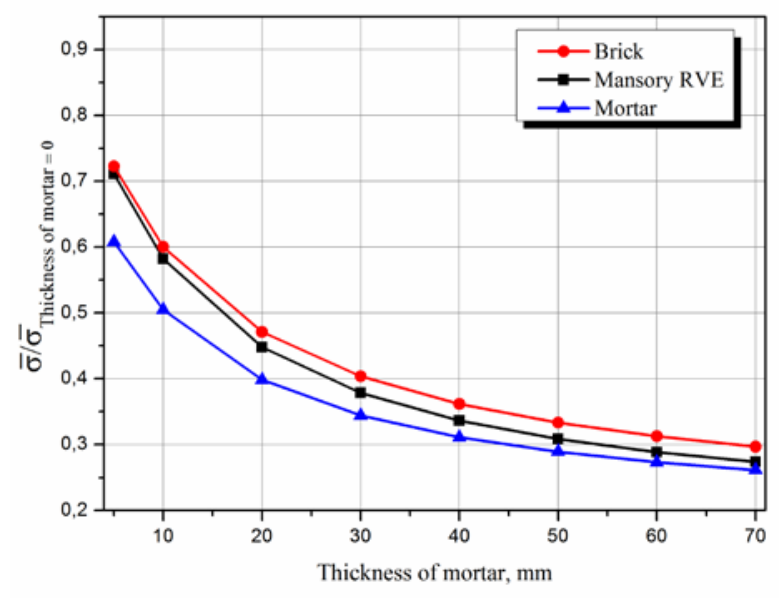

b)

Figure 9. Influence of the thickness of mortar on the von Mises stress intensity averaged over the whole volume of RVE and over its individual components:

a) under compression in horizontal direction; b) under compression in vertical direction

Grishchenko A.I. Semenov A.S., Semenov S.G., Melnikov B.E. Influence of structural parameters of masonry on effective elastic properties and strength 


\subsection{Influence of Brick Aspect Ratio}

In building practice bricks and stones of various proportions are used. Due to this fact, it is necessary to study the influence of the brick aspect ratio on the stress-strain state and on the effective elastic moduli of the masonry.

In order to evaluate the influence of the bricks aspect ratio on the stress-strain state and on the effective elastic moduli of RVE, FE calculations are carried out with different bricks aspect ratio: 1, 2, $3, \ldots, 10$ (FE models are shown in Figure 10). The results of computational experiments have shown that the bricks aspect ratio considerably affects the effective moduli (Fig. 11) and the von Mises stress intensity averaged over the whole volume of RVE and over its individual components (Fig. 12).

The results of the computational experiments have shown that the bricks aspect ratio does not practically affect the $\bar{E}_{1}$ (change in the elastic modulus is less $7 \%$ ) (Fig. 11), but it has considerable influence on the effective elastic moduli $\bar{E}_{2}$ (Fig. 11). The increase of the bricks aspect ratio from 1 up to 10 leads to decreases of $\bar{E}_{2}$ by $35 \%$.

The same increase of the bricks aspect ratio under compression in horizontal direction leads to the varying von Mises stress intensity:

- increase by $6.6 \%$ for averaging over the whole volume of RVE;

- increase by $20.9 \%$ for averaging over the whole volume of brick;

- decrease by $81.4 \%$ for averaging over the whole volume of mortar.

The same increase of the bricks aspect ratio under compression in vertical direction leads to the varying von Mises stress intensity:

- decrease by $34.9 \%$ for averaging over the whole volume of RVE;

- decrease by $40.7 \%$ for averaging over the whole volume of brick;

- increase by $7.6 \%$ for averaging over the whole volume of mortar.

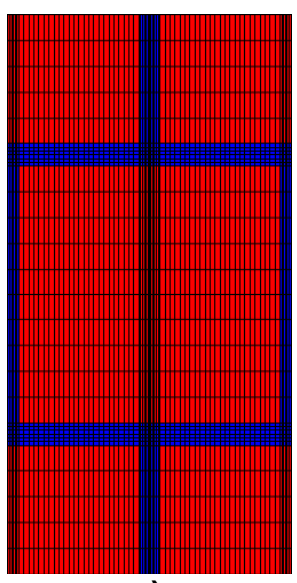

a)

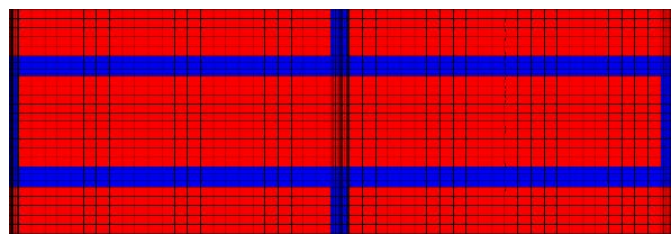

c)

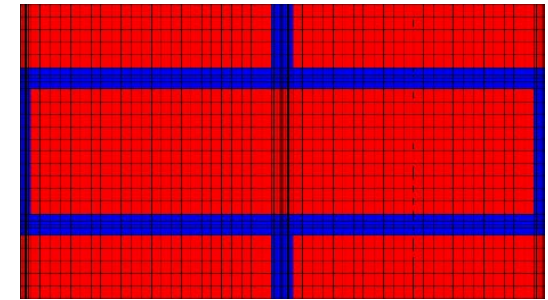

b)

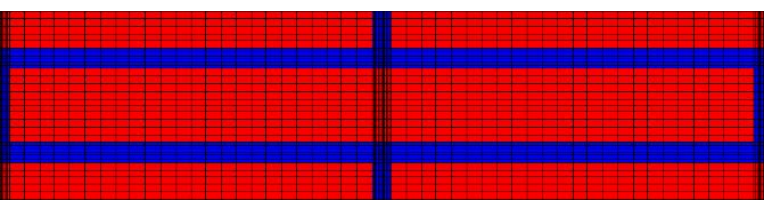

d)

Figure 10. FE model for various bricks aspect ratio:

a) $I / h=1 ;$ b) $I / h=4$; c) $I / h=7$; d) $I / h=10$

Grishchenko A.I. Semenov A.S., Semenov S.G., Melnikov B.E. Influence of structural parameters of masonry on effective elastic properties and strength 


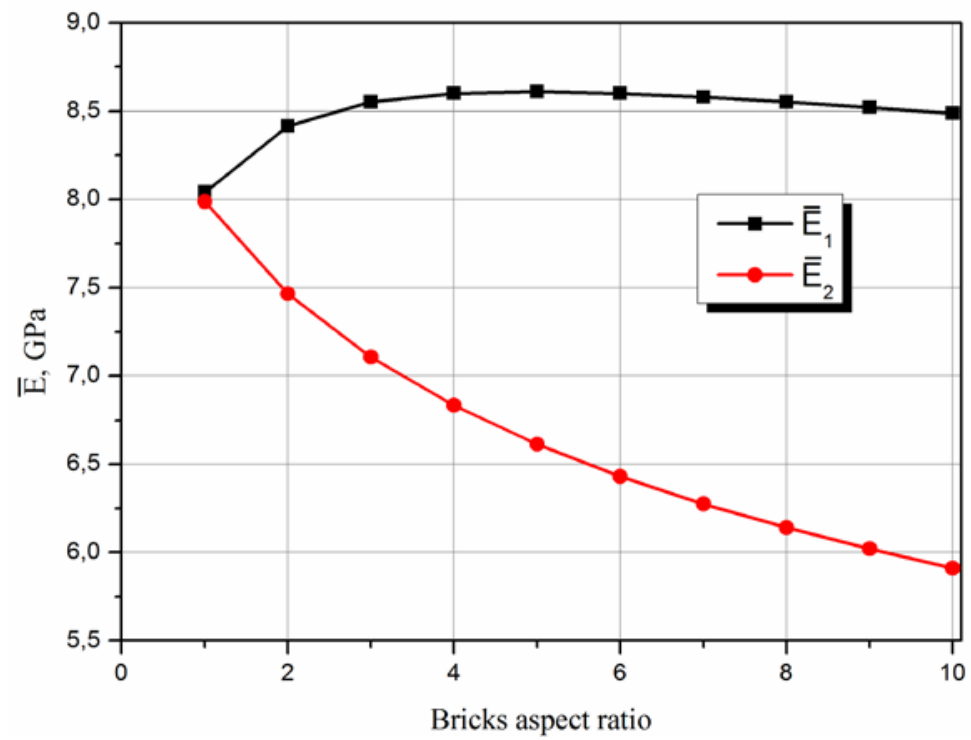

Figure 11. Dependence of the elastic moduli of masonry RVE on the bricks aspect ratio

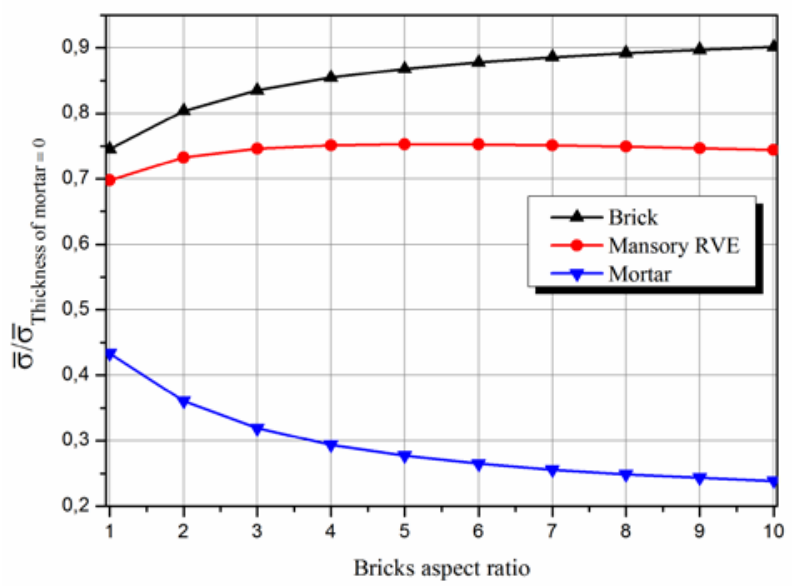

a)

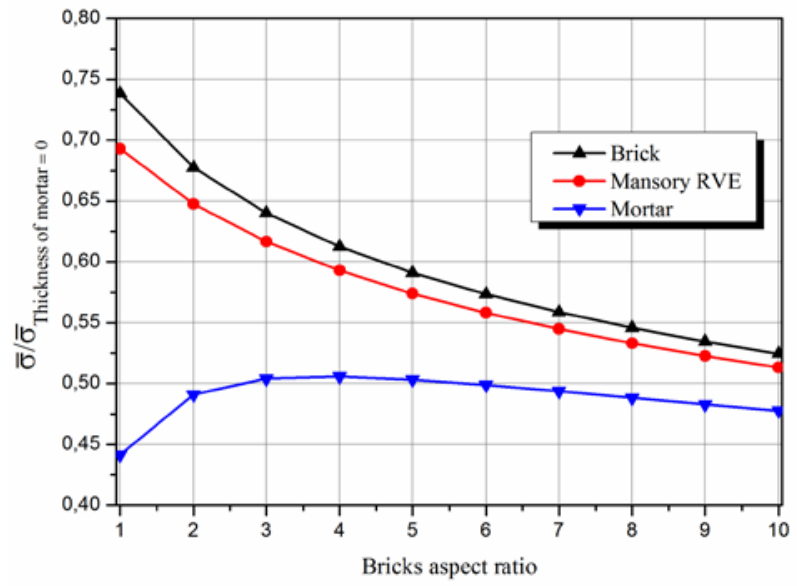

b)

Figure 12. Influence of the brick aspect ratio on the von Mises stress intensity averaged over the whole volume of RVE and over its individual components: a) under compression in horizontal direction, b) under compression in vertical direction

The elastic modulus $E_{1}$ does not change monotonically with increase of the brick aspect ratio. $E_{1}$ has a maximum value at $l / h=5$. This aspect ratio corresponds to the typical brick aspect ratio used traditionally in practice.

\subsection{Comparison of Different Homogenization Approaches}

Comparison of the numerical results obtained for the effective elastic moduli of the masonry with the results of other numerical or analytical approaches $[5,6,7,9,10]$ is summarized in Table 2 . The results of the current investigation of FE homogenization and use of boundary conditions of periodicity, are in a good consistency with other approaches based on FEM [5, 9, 10]. Appreciable differences are observed with the two-step method [6] and with the elliptical cylinder model [7].

Grishchenko A.I. Semenov A.S., Semenov S.G., Melnikov B.E. Influence of structural parameters of masonry on effective elastic properties and strength 
Table 2. Effective elastic properties of masonry

\begin{tabular}{|c|c|c|c|}
\hline Method of homogenization & $\begin{array}{c}\bar{E}_{1}, \\
\text { GPa }\end{array}$ & $\begin{array}{c}\bar{E}_{2}, \\
\text { GPa }\end{array}$ & $\begin{array}{c}\bar{v}_{12}, \\
{[-]}\end{array}$ \\
\hline FEM, stack bond [10] & 8.530 & 6.790 & 0.196 \\
\hline Periodic FEM model (current investigation) & 8.609 & 6.708 & 0.200 \\
\hline FEM, running bond [10] & 8.620 & 6.770 & 0.200 \\
\hline Periodic model, stack bond [9] & 8.568 & 6.850 & 0.191 \\
\hline Periodic model, running bond [9] & 8.574 & 6.809 & 0.197 \\
\hline Multilayer method Pande et al. [5] & 8.525 & 6.906 & 0.208 \\
\hline Two-step method [6] & 9.187 & 6.588 & 0.215 \\
\hline Elliptical cylinder model [7] & 7.784 & 6.315 & 0.247 \\
\hline
\end{tabular}

\section{Further Research}

The next stage of research implies further finite element modeling of the fracture process of masonry based on the approaches used in [14-19] with due consideration of experimental and numerical results of masonry $[13,20-24]$ and results of these investigations. One of the most promising approaches for fracture of concrete structures is a continuum damage mechanics approach [25-30]. The accuracy of computation can be improved by using non-linear material models [19, 30-32].

\section{Conclusions}

1. Effective elastic moduli of the masonry RVE have been obtained by means of the finite element homogenization under assumption of the resulting orthotropic elastic properties.

2. Multivariant numerical experiments with varying parameters characterizing masonry have been performed. The effects of orientation of bricks on the stress state of masonry RVE have been analyzed.

3. Influence of the brick aspect ratio and mortar thickness on the effective elastic moduli and stress state of masonry has been investigated.

\section{References}

1. Gambarotta G., Lagomarsino S. Damage models for the seismic response of brick masonry shear walls. Part I: The mortar joint model and its applications. Earthquake Engineering \& Structural Dynamics. 1997. Vol. 26. Issue 4. Pp. 423-439.

2. Michel J.C., Moulinec H., Suquet P. Effective properties of composite materials with periodic microstructure: A computational approach. Computer Methods in Applied Mechanics and Engineering. 1999. Vol. 172. Issues 1-4. Pp. 109-143.

3. Giambanco G., Rizzo S., Spallino R. Numerical analysis of masonry structures via interface models. Computer Methods in Applied Mechanics and Engineering. 2001. Vol. 190. Issues 49-50. Pp. 6493-6511.

4. Formica, G., Sansalone, V., and Casciaro, R. A mixed solution strategy for the nonlinear analysis of brick masonry walls. Computer Methods in Applied Mechanics and Engineering. 2002. Vol. 191. Issues 51-52. Pp. 5847-5876.

5. Pande G.N., Liang J.X., Middleton J. Equivalent elastic moduli for brick masonry. Computers and Geotechnics. 1989. Vol. 8. Issue 3. Pp. 243-265.

6. Pietruszczak S., Niu X. A mathematical description of macroscopic behavior of brick masonry. International Journal of Solids and Structures. 1998. Vol. 29(5). Pp. 531-546.

7. Mori T., Tanaka K. Average stress in the matrix and average elastic energy of materials with misfitting inclusions. Acta Metallurgica. 1973. Vol. 21. Pp. 571-574.

8. Bati S.B., Ranocchiai G., Rovero L. Suitability of micromechanical model for elastic analysis of masonry. Journal of Engineering Mechanics. 1999. Vol. 125(8). Pp. 922-929.

9. Wang G., Li S., Nguyen H.-N. Sitar N. Effective Elastic Stiffness for Periodic Masonry Structures via Eigenstrain Homogenization. Journal of Materials in Civil Engineering. 2007. Vol. 19(3). Pp. 269-277.

Grishchenko A.I. Semenov A.S., Semenov S.G., Melnikov B.E. Influence of structural parameters of masonry on effective elastic properties and strength 
10. Anthoine A. Derivation of the in-plane elastic characteristics of masonry through homogenization theory. International Journal of Solids and Structures. 1995. Vol. 32(20). Pp. 137-163.

11. GOST 530-2012. Kirpich i kamen keramicheskiye. Obshchiye tekhnicheskiye usloviya [GOST 530-2012. Ceramic brick and stone. General specifications]. Moscow, 2013. (rus)

12. Pangaev V.V. Vliyanye marok kirpicha i rastvora na napriazhenno-deformirovannoye sostoianye kamennoy cladki [Influence of the brands of brick and mortar on the stress-strain state of the masonry]. Nauchnyye trudy Obshchestva zhelezobetonshchikov Sibiri i Urala: sb. materialov 11-y Sib. (mezhdunar.) konf. / pod red. V. V. Gabrusenko [Proceedings of the concrete workers' society of Siberia and Ural $-11^{\text {th }}$ International conference. Edited by V.V. Gabrushenko]. Novosibirsk: NGASU, 2006. Vol. 9. Pp. 72-75. (rus)

13. Semenov A.S. PANTOCRATOR- konechno-elementyy programmnyy kompleks, orientirovannyy na resheniye nelineynykh zadach mehaniki [PANTOCRATOR-finite-element software package, focused on the solution of nonlinear problems in mechanics]. Trudy Mezhdunarodnoy konferentsii "Nauchnotekhnicheskiye problemy prognozirovaniya nadezhnosti $i$ dolgovechnosti konstruktsii $i$ metody ikh resheniya" [Proceedings of $\mathrm{V}$ International conference "Scientific and technical problems of predicting the reliability and durability of the structures and methods of solving them"]. Saint-Petersburg: SPbGPU, 2003. Pp. 466-480. (rus)

14. Bolzon G., Ghilotti D., Maier G. Strength of periodic elastic-brittle composites evaluated through homogenization and parameter identification. European Journal of Mechanics - A/Solids. 2002. Vol. 21. Issue 3. Pp. 355-378.

15. Semenov A., Semenov S., Nazarenko A., Getsov L. Computer simulation of fatigue, creep and thermalfatigue cracks propagation in gas-turbine blades. Materiali in Tehnologije. 2012. Vol. 46. No. 3. Pp. 197-203.

16. Bahr H.A., Balke H., Fett T., Hofinger I., Kirchhoff G., Munz D., Neubrand A., Semenov A.S., Weiss H.J., Yang Y.Y. Cracks in functionally graded materials. Materials Science and Engineering: A. 2003. Vol. 362. No.1-2. Pp. 2-16.

17. Semenov A.S., Bahr H.A., Balke H., Weiss H.J. Contact-driven delamination and spalling of coatings due to cyclic shock heating. The Solid Films. 2005. Vol. 471. №1-2. Pp. 200-208.

18. Getsov L., Semenov A., Staroselsky A. A failure criterion for single-crystal superalloys during thermocyclic loading. Materiali in Tehnologije. 2008. Vol. 42. No. 1. Pp. 3-12.

19. Wu C., Hao H. Derivation of 3D masonry properties using numerical homogenization technique. International Journal for Numerical Methods in Engineering. 2006. Vol. 66. Issue 11. Pp. 1717-1737.

20. Derkach V.N. Prochnost normalnogo stsepleniya tsementnykh rastvorov $v$ kamennoy kladke [Normal cohesion strength of cement mortar in masonry]. Magazine of Civil Engineering. 2012. No. 7(33). Pp. 613. (rus).

21. Kashevarova G.G., Zobacheva A.lu. Modelirovaniye protsessa razrusheniya kirpichnoy kladki [Modeling of masonry fracture process]. PNRPU Mechanics Bulletin. 2010. No.1. Pp. 106-116. (rus).

22. Antakov A.B., Sokolov B.S., Fabrichnaia K.A. Issledovaniya kladok iz pustotelogo kirpicha 1,4 NF [Research of masonry from a hollow brick]. News of the Kazan State University of Architecture and Engineering. 2009. No. 2(12). Pp. 134-139. (rus)

23. Pangaev V.V. Model razrusheniya kamennoy kladki pri szhatii [Model of masonry fracture under compression]. Nauchnyye trudy Obshchestva zhelezobetonshchikov Sibiri i Urala: sb. materialov 8-y Sib. (mezhdunar.) konf. / pod red. Gabrusenko V. V. [Proceedings of the concrete workers' society of Siberia and Ural - 8th International conference. Edited by V.V. Gabrushenko]. Novosibirsk: NGASU, 2000. Vol. 6. Pp. 31-35. (rus).

24. Pangaev V.V. Razrusheniye szhatoy kamennoy kladki [Fracture of compressed masonry]. News of Higher Educational Institutions. Construction. 2000. No.12. Pp. 7-12. (rus).

25. Benin A.V., Semenov A.S., Semenov S.G. Modelirovaniye protsessa razrusheniya elementov zhelezobetonnykh konstruktsiy pod deystviyem korrozii armatury [Modeling of Fracture Process in Concrete Reinforced StructureS Under Steel Corrosion]. Proceedings of Petersburg Transport University. 2010. Vol. 39. No.2. Pp. 168-175. (rus).

26. Semenov A.S. Mehanika nelokalnykh kontinualnykh povrezhdeniy [Non-local continuum damage mechanics]. St. Petersburg State Polytechnical University Journal. 2006. No.6-1(48) Pp. 148-159. (rus).

Grishchenko A.I. Semenov A.S., Semenov S.G., Melnikov B.E. Influence of structural parameters of masonry on effective elastic properties and strength 
27. Benin A.V., Semenov A.S., Semenov S.G., Melnikov B.E. Matematicheskoye modelirovaniye protsessa razrusheniya stsepleniya armatury $s$ betonom Chast 1 . Modeli $s$ uchetom nesploshnosti soyedineniya [Simulation of degradation of bond between reinforcing bar and concrete. Part 1. Models with account of the discontinuity]. Magazine of Civil Engineering. 2013. No.5(40). Pp. 86-99. (rus).

28. Benin A.V., Semenov A.S., Semenov S.G., Melnikov B.E. Matematicheskoye modelirovaniye protsessa razrusheniya stsepleniya armatury $s$ betonom. Chast 2 . Modeli bez ucheta nesploshnosti soedineniya [The simulation of bond fracture between reinforcing bars and concrete. Part 2. Models without taking the bond discontinuity into account]. Magazine of Civil Engineering. $2014 . \quad$ No.1(45). Pp. 23-40. (rus).

29. Benin A.V., Semenov A.S., Semenov S.G., Melnikov B.E. Konechno-elementnoye modelirovaniye protsessov razrusheniya i otsenka resursa elementov avtodorozhnogo mosta s uchyotom korrozionnykh povrezhdeniy [Finite element modeling of fracture processes and estimation of durability of the road bridge with account of corrosion damages]. Magazine of Civil Engineering. 2013. No. 7(33). Pp. 32-42. (rus)

30. Sacco E. A nonlinear homogenization procedure for periodic masonry. European Journal of Mechanics A/Solids. 2009. Vol. 28. Pp. 209-222.

31. Semenov A. S. Vychislitelnyye metody $v$ teorii plastichnosti [Computational methods in the theory of plasticity]. Saint-Petersburg: Izd-vo SPbGPU, 2008. 211 p. (rus)

32. Melnikov B.E., Semenov A.S., Semenov S.G. Mnogomodelnyy analiz uprugoplasticheskogo deformirovaniya materialov i konstruktsiy [Analysis of multi-model of elastic-plastic deformation of materials and designs. State of the art]. Trudy TsNII im. akad. A. N. Krylova [Proceedings of Krylov Shipbuilding Research Institute]. 2010. No.53. Pp. 85-92. (rus)

Alexey I. Grishchenko, St.-Petersburg, Russia +7(921)920-09-88; e-mail: gai-gr@yandex.ru

Artem S. Semenov, St.-Petersburg, Russia +7(905)2721188; e-mail: Semenov.Artem@googlemail.com

Sergey G. Semenov, St.-Petersburg, Russia +7(921)983-44-56; e-mail: ssgrus@gmail.com

Boris E. Melnikov, St.-Petersburg, Russia +7(812)552-63-03; e-mail: kafedra@ksm.spbstu.ru

(c) Grishchenko A.I., Semenov A.S.., Semenov S.G., Melnikov B.E., 2014

Grishchenko A.I. Semenov A.S., Semenov S.G., Melnikov B.E. Influence of structural parameters of masonry on effective elastic properties and strength 
doi: 10.5862/MCE.49.10

\title{
Влияние структурных параметров кладки на эффрективные упругие свойства и прочность
}

\author{
студент А.И. Грищенко \\ Санкт-Петербургский государственный политехнический университет, \\ Санкт-Петербург, Россия \\ Тел. моб.: +79219200988; эл. почта: gai-gr@yandex.ru \\ к. ф.-м.н., доцент А.С. Семенов \\ Санкт-Петербургский государственный политехнический университет, \\ Санкт-Петербург, Россия \\ Тел. моб.: +79052721188; эл. почта: Semenov.Artem@googlemail.com \\ инженер С.Г. Семенов \\ Санкт-Петербургский государственный политехнический университет, \\ Санкт-Петербург, Россия \\ Тел. моб.: +79219834456; эл. почта: ssgrus@gmail.com \\ д.т.н., заведущий кафедрой Б.Е. Мельников \\ Санкт-Петербургский государственный политехнический университет, \\ Санкт-Петербург, Россия \\ Тел. раб.: +78125526303; эл. почта: kafedra@ksm.spbstu.ru
}

\section{Ключевые слова}

кладка; композиционные материалы; элементарный представительный объем; гомогенизация; численный эксперимент; граничные условия периодичности; эфффективные упругие модули; метод конечных элементов; PANTOCRATOR

\section{Аннотация}

С целью произведения оценки эффективных упругих модулей и прочностных свойств кирпичной кладки анализируется ее модель, представляющая собой эластичный раствор и упругие кирпичи. Рассмотрены различные методы гомогенизации кирпичной кладки.

При помощи прямого конечно-элементного моделирования и процедуры усреднения определены эффективные упругие свойства элементарного представительного объема кирпичной кладки в предположении ортотропии её компонент. Выполнен анализ влияния вариации микроструктурных характеристик гетерогенного материала (влияние соотношением сторон кирпича и угла ориентации) на локальное напряженно-деформированное состояние и механических свойств элементарного представительного элемента объема рассматриваемого композита. Выполнено сравнение механических свойств, полученных путем прямого конечноэлементного моделирования и полученных при помощи других методов в различных литературных источниках.

Данные исследования актуальны для проектирования композиционных материалов со структурой, аналогичной кирпичной кладки.

\section{Лumepamypa}

1. Gambarotta G., Lagomarsino S. Damage models for the seismic response of brick masonry shear walls. Part I: The mortar joint model and its applications // Earthquake Engineering \& Structural Dynamics. 1997. Vol. 26. Issue 4. Pp. 423-439.

2. Michel J.C., Moulinec H., Suquet P. Effective properties of composite materials with periodic microstructure: A computational approach // Computer Methods in Applied Mechanics and Engineering. 1999. Vol. 172. Issues 1-4. Pp. 109-143.

3. Giambanco G., Rizzo S., Spallino R. Numerical analysis of masonry structures via interface models // Computer Methods in Applied Mechanics and Engineering. 2001. Vol. 190. Issues 49-50. Pp. 6493-6511.

4. Formica G., Sansalone V., Casciaro, R. A mixed solution strategy for the nonlinear analysis of brick masonry walls // Computer Methods in Applied Mechanics and Engineering. 2002. Vol. 191. Issues 51-52. Pp. 5847-5876.

5. Pande G.N., Liang J.X., Middleton J. Equivalent elastic moduli for brick masonry // Computers and Geotechnics. 1989. Vol. 8. Issue 3. Pp. 243-265.

Грищенко А.И., Семенов А.С., Семенов С.Г., Мельников Б.Е. Влияние структурных параметров кладки на эффективные упругие свойства и прочность 
6. Pietruszczak S., Niu X. A mathematical description of macroscopic behavior of brick masonry // International Journal of Solids and Structures. 1998. Vol. 29(5). Pp. 531-546.

7. Mori T., Tanaka K. Average stress in the matrix and average elastic energy of materials with misfitting inclusions // Acta Metallurgica. 1973. Vol. 21. Pp. 571-574.

8. Bati S.B., Ranocchiai G., Rovero L. Suitability of micromechanical model for elastic analysis of masonry // Journal of Engineering Mechanics. 1999. Vol. 125(8). Pp. 922-929.

9. Wang G., Li S., Nguyen H.-N. Sitar N. Effective Elastic Stiffness for Periodic Masonry Structures via Eigenstrain Homogenization // Journal of Materials in Civil Engineering. 2007. Vol. 19(3). Pp. 269-277.

10. Anthoine A. Derivation of the in-plane elastic characteristics of masonry through homogenization theory. International Journal of Solids and Structures. 1995. Vol. 32(20). Pp. 137-163.

11. ГОСТ 530-2012. Кирпич и камень керамические. Общие технические условия. Москва, 2013.

12. Пангаев В.В. Влияние марок кирпича и раствора на наприаженно-деформированное состояние каменной кладки // Научные труды Общества железобетонщиков Сибири и Урала: сб. малтериалов 11-й Сиб. (междунар.) конф. / Под ред. В. В. Габрусенко. Новосибирск: НГАСУ, 2006. Вып. 9. С. 7275.

13. Семёнов A.C. PANTOCRATOR- конечно-элементный программный комплекс, ориентированный на решение нелинейных задач механики // Труды Международной конференции «Научно-технические проблемы прогнозирования надежности и долговечности конструкций и методы их решения». С.Петербург, 14-17 октября 2003. СПб.: Изд-во СПбГПУ, 2003. С. 466-480.

14. Bolzon G., Ghilotti D., Maier G. Strength of periodic elastic-brittle composites evaluated through homogenization and parameter identification // European Journal of Mechanics - A/Solids. 2002. Vol. 21. Issue 3. Pp. 355-378.

15. Semenov A., Semenov S., Nazarenko A., Getsov L. Computer simulation of fatigue, creep and thermalfatigue cracks propagation in gas-turbine blades // Materiali in Tehnologije. 2012. Vol. 46. No. 3. Pp. 197-203.

16. Bahr H.A., Balke H., Fett T., Hofinger I., Kirchhoff G., Munz D., Neubrand A., Semenov A.S., Weiss H.J., Yang Y.Y. Cracks in functionally graded materials // Materials Science and Engineering: A. 2003. Vol. 362. No.1-2. Pp. 2-16.

17. Semenov A.S., Bahr H.A., Balke H., Weiss H.J. Contact-driven delamination and spalling of coatings due to cyclic shock heating // The Solid Films. 2005. Vol. 471. No.1-2. Pp. 200-208.

18. Getsov L., Semenov A., Staroselsky A. A failure criterion for single-crystal superalloys during thermocyclic loading // Materiali in Tehnologije. 2008. Vol. 42. No. 1. Pp. 3-12.

19. Wu C., Hao H. Derivation of 3D masonry properties using numerical homogenization technique // International Journal for Numerical Methods in Engineering. 2006. Vol. 66. Issue 11. Pp. 1717-1737.

20. Деркач В.Н. Прочность нормального сцепления цементных растворов в каменной кладке // Инженерно-строительный журнал. 2012. №7(33). С. 6-13.

21. Кашеварова Г.Г., Зобачева А.Ю. Моделирование процесса разрушения кирпичной кладки // Вестник Пермского национального исследовательского политехнического университета. Строительство и архитектура. 2010. № 1. С. 106-116.

22. Антаков А.Б., Соколов Б.С., Фабричная К.А. Исследования кладок из пустотелого кирпича 1,4 НФ. Известия Казанского государственного архитектурно-строительного университета, 2009, стр. 134 139.

23. Пангаев В.В. Модель разрушения каменной кладки при сжатии // Научные труды Общества железобетонщиков Сибири и Урала: сб. материалов 8-й Сиб. (междунар.) конф. / Под ред. Габрусенко В.В. Новосибирск: НГАСУ, 2000. Вып. 6. С. 31-35.

24. Пангаев В.В. Разрушение сжатой каменной кладки // Известия вузов. Строительство. 2000. №12. С. 7-12.

25. Бенин А.В., Семенов А.С., Семенов С.Г. Моделирование процесса разрушения элементов железобетонных конструкций под действием коррозии арматуры // Известия петербургского университета путей сообщения. 2010. Вып. 29. №2. С. 168-175.

26. Семёнов А.С. Механика нелокальных континуальных повреждений // Научно-технические ведомости Санкт-Петербургского государственного технического университета. 2006. №6-1(48) С. 148-159.

27. Бенин А.В., Семенов А.С., Семенов С.Г., Мельников Б.Е. Математическое моделирование процесса разрушения сцепления арматуры с бетоном Часть 1. Модели с учетом несплошности соединения // Инженерно-строительный журнал. 2013. №5(40). С. 86-99.

Грищенко А.И., Семенов А.С., Семенов С.Г., Мельников Б.Е. Влияние структурных параметров кладки на эффективные упругие свойства и прочность 
28. Бенин А.В., Семенов А.С., Семенов С.Г., Мельников Б.Е. Математическое моделирование процесса разрушения сцепления арматуры с бетоном. Часть 2. Модели без учета несплошности соединения // Инженерно-строительный журнал. 2014. №1(45). С. 23-40.

29. Бенин А.В., Семенов А.С., Семенов С.Г., Мельников Б.Е. Конечно-элементное моделирование процессов разрушения и оценка ресурса элементов автодорожного моста с учётом коррозионных повреждений // Инженерно-строительный журнал. 2012. №7(33). С. 32-42.

30. Sacco E. A nonlinear homogenization procedure for periodic masonry // European Journal of Mechanics A/Solids. 2009. Vol. 28. Pp. 209-222.

31. Семенов А. С. Вычислительные методы в теории пластичности. Изд-во СПбГПУ. 2008. 211 с.

32. Мельников Б.Е., Семенов А.С., Семенов С.Г. Многомодельный анализ упругопластического деформирования материалов и конструкций. Современное состояние // Труды ЦНИИ им. акад. А. Н. Крылова. 2009. Вып. 53. С. 85-92.

Полный текст статьи на английском языке: с. 95-106 